IZA DP No. 5651

A Call for Comparative Research: Consequences of a Rising Income Inequality for State Activities

Renate Neubäumer

April 2011 


\title{
A Call for Comparative Research: Consequences of a Rising Income Inequality for State Activities
}

\author{
Renate Neubäumer \\ University of Koblenz-Landau \\ and IZA
}

\section{Discussion Paper No. 5651 \\ April 2011}

IZA

P.O. Box 7240

53072 Bonn

Germany

Phone: +49-228-3894-0

Fax: +49-228-3894-180

E-mail: iza@iza.org

Any opinions expressed here are those of the author(s) and not those of IZA. Research published in this series may include views on policy, but the institute itself takes no institutional policy positions.

The Institute for the Study of Labor (IZA) in Bonn is a local and virtual international research center and a place of communication between science, politics and business. IZA is an independent nonprofit organization supported by Deutsche Post Foundation. The center is associated with the University of Bonn and offers a stimulating research environment through its international network, workshops and conferences, data service, project support, research visits and doctoral program. IZA engages in (i) original and internationally competitive research in all fields of labor economics, (ii) development of policy concepts, and (iii) dissemination of research results and concepts to the interested public.

IZA Discussion Papers often represent preliminary work and are circulated to encourage discussion. Citation of such a paper should account for its provisional character. A revised version may be available directly from the author. 
IZA Discussion Paper No. 5651

April 2011

\section{ABSTRACT \\ A Call for Comparative Research: Consequences of a Rising Income Inequality for State Activities}

The aim of this discussion paper is not only to activate a debate over the interrelation between rising income inequality and economic policy measures but also to initiate comparative research in several European countries and North America. It discusses the consequences of a rising income inequality and its implications for state activities and economic policy. Using a simple model it becomes evident that an increasing income inequality leads to higher government spending, as a share of Gross Domestic Product, though the state does not take over more responsibilities. It also leads to a higher tax share though rates of taxation are not increased. This forces economic politicians to act. If they want to prevent an increase of these shares in order not to fall behind in the international competition, they must accept a rising public debt and/or must move away from socially accepted value judgments about "social standards", the degree of redistribution by taxes and/or an "adequate" supply of public goods. This might result in disenchantment with politics.

JEL Classification: E6

Keywords: economic policy, income inequality, macroeconomic key figures, state activities

Corresponding author:

Renate Neubäumer

University of Koblenz-Landau

Institute of Social Sciences

Department of Economics

August-Croissant-Straße 5

D-76829 Landau

Germany

E-mail: neub@uni-landau.de 


\section{A Call for Comparative Research - Consequences of a Rising Income Inequality for State Activities}

In many OECD-countries a rising income concentration could be - and can be - observed and has been discussed widely (e.g. OECD, 2008; International Monetary Fund, 2007; Berthold, 2007, Krämer, 2005; Atkinson, 2003, Alderson and Nelsen, 2002, Gottschalk and Smeeding, 1997). After the Second World War the distribution of incomes had become more equal at first, but since the early to mid-1970s a long-lasting rise in income inequality started. Therefore Harrison and Bluestone (1988) refer to the "great u-turn" (though Gustafsson and Johansson, (1999) contradict this concept). First, a rising income concentration is proven by a considerable decrease in wage ratios indicating a redistribution from earners of wage incomes to proprietors of capital. Second, differences in earned incomes increased as incomes at the top "exploded" while medium incomes grew moderately and low incomes nearly stagnated.

On the contrary, it was hardly discussed what are the implications of an increased income inequality would be for state activities and for the strategical options of economic policy and hence for the attitude towards politics of citizens (and voters).

The object of this paper is not only to activate a debate over the interrelation between rising income inequality and economic policy measures but also to initiate comparative research in several European countries and North America. We would especially like to draw attention to the following questions:

- Does a considerable increase of income inequality lead to less redistribution of market incomes by the government and furthermore to a lower amount of basic social care (lower "social standards")? and

Does a higher income concentration cause a lower supply with public goods?

- Do citizens accept, in this context, that politicians move away from previous, socially accepted value judgements?

The plan of our short discussion paper is as follows: In Section 1 the implications of rising income inequality for taxes, transfer payments and government spending, as a share of Gross Domestic Product (GDP), are demonstrated with a simple model. Section 2 discusses why this puts (economic) politicians under the obligation to act and which options of reaction they have. Section 3 concludes with an outlook on further research, determining which empirical investigations would be interesting for different countries, and is simultaneously a call for comparative research.

\section{A simple model}

We have designed a simple theoretical approach to demonstrate the effects of rising income inequality on public revenue and public spending, assuming:

A country's income distribution can be characterized by the average income of income earners below the median $\left(\bar{Y}_{1}\right)$ and above the median $\left(\bar{Y}_{2}\right)$ defining 


$$
\overline{\mathrm{Y}}_{1}=\sum_{\mathrm{i}=1}^{\mathrm{n} / 2} \mathrm{Y}_{\mathrm{i}}: \frac{\mathrm{n}}{2} \text { and } \overline{\mathrm{Y}}_{2}=\sum_{\mathrm{i}=(\mathrm{n} / 2)+1}^{\mathrm{n}} \mathrm{Y}_{\mathrm{i}}: \frac{\mathrm{n}}{2}
$$

(Respectively the total income below the median $\left(\mathrm{Y}_{1}\right)$ and above the median $\left(\mathrm{Y}_{2}\right)$ is:

$$
\left.\mathrm{Y}_{1}=\sum_{\mathrm{i}=1}^{\mathrm{n} / 2} \mathrm{Y}_{\mathrm{i}} \text { and } \mathrm{Y}_{2}=\sum_{\mathrm{i}=(\mathrm{n} / 2)+1}^{\mathrm{n}} \mathrm{Y}_{\mathrm{i}}\right)
$$

Accordingly, the average income in the economy is:

and the total income amounts to:

$$
\mathrm{Y}=\frac{\mathrm{n}}{2} \cdot \overline{\mathrm{Y}}_{1}+\frac{\mathrm{n}}{2} \cdot \overline{\mathrm{Y}}_{2}=\mathrm{Y}_{1}+\mathrm{Y}_{2} \text {. }
$$

We speak of a concentration of the income distribution if the total income (Y) remains constant while the income in the upper half $\left(\mathrm{Y}_{2}\right)$ increases and the income in the lower half $\left(\mathrm{Y}_{1}\right)$ decreases and hence the following equation applies:

$$
\Delta \mathrm{Y}_{2}=-\Delta \mathrm{Y}_{1} \text {. }
$$

Thereby we assume, which is of course a simplification, that the income distribution within both halves does not change, i.e. all $Y_{i}$, for which applies $i \leq n / 2$, decrease by the same percentage and all $Y_{i}$, for which applies $i>n / 2$, increase by the same percentage.

The system of taxation only consists of an income tax and earners of both income groups are taxed with a unitary rate $t_{1}$ and $t_{2}$ respectively. (There is no tax-free amount.)

There is a simple system of transfer payments: Earners with an income falling below a certain minimum income $\left(\mathrm{Y}_{\mathrm{min}}\right)$ get transfer payments. Accordingly, public spending for transfer payments (Tr) adds up to:

$$
\begin{array}{rlr}
\operatorname{Tr} & =\operatorname{tr} \cdot \sum_{\mathrm{i}=1}^{\mathrm{n}} \mathrm{Y}_{\mathrm{Tr}_{\mathrm{i}}} \text { with } \mathrm{Y}_{\mathrm{Tr}_{\mathrm{i}}}=\mathrm{Y}_{\min }-\mathrm{Y}_{\mathrm{i}} \text { for } \mathrm{Y}_{\min }>Y_{\mathrm{i}} \\
& \text { and } \mathrm{Y}_{\mathrm{Tr}_{\mathrm{i}}}=0 \quad \text { for } \mathrm{Y}_{\min } \leq \mathrm{Y}_{\mathrm{i}} \\
& =\mathrm{tr} \cdot \mathrm{Y}_{\mathrm{Tr}} \text {. }
\end{array}
$$

(In the equation tr is the transfer rate, $\mathrm{Y}_{\mathrm{Tr}_{\mathrm{i}}}$ is the assessment basis for the transfer payment of the ith income earner and $\mathrm{Y}_{\mathrm{Tr}}$ is the macroeconomic assessment basis.)

Public revenue equal tax revenue (T) amounting to:

$$
\mathrm{T}=\mathrm{t}_{1} \cdot \mathrm{Y}_{1}+\mathrm{t}_{2} \cdot \mathrm{Y}_{2}
$$

Public spending $(\mathrm{G})$ includes transfer payments $(\mathrm{Tr})$ and spending for public consumption $\left(\mathrm{C}_{\mathrm{G}}\right)$ and for public investment $\left(\mathrm{I}_{\mathrm{G}}\right)$ :

$$
\mathrm{G}=\operatorname{Tr}+\mathrm{C}_{\mathrm{G}}+\mathrm{I}_{\mathrm{G}} \cdot
$$

In the initial situation the budget is balanced, i.e. the following equation is met:

$$
\mathrm{T}=\mathrm{G}=\mathrm{Tr}+\mathrm{C}_{\mathrm{G}}+\mathrm{I}_{\mathrm{G}} .
$$


Thereby the following factors are the result of social value judgements in a country:

- The transfer rate tr and the minimum income $\mathrm{Y}_{\min }$, below which an individual gets transfer payments. (For tr $=1$, all lower market incomes add up to $\mathrm{Y}_{\min }$.)

- Public spending for consumption and for investment. These mirror which duties and responsibilities the government should take and which supply with public goods is seen as "adequate".

- The tax rates $t_{1}$ and $t_{2}$. They reflect how much the citizens should pay for public goods and to what degree incomes should be redistributed.

\section{Implications of rising income inequality for state activities}

If $\mathrm{Y}_{2} / \mathrm{Y}_{1}$ increases, while the total income $\mathrm{Y}$ is remaining unchanged we interpret this as a higher concentration of the income distribution. In that case $\Delta \mathrm{Y}_{2}=-\Delta \mathrm{Y}_{1}$ applies.

This has - ceteris paribus - far-reaching consequences for government revenue and spending and hence for state activities:

- Tax revenue increases by

$$
\Delta \mathrm{T}=\mathrm{t}_{2} \cdot \Delta \mathrm{Y}_{2}+\mathrm{t}_{1} \cdot \Delta \mathrm{Y}_{1}=\left(\mathrm{t}_{2}-\mathrm{t}_{1}\right) \cdot \Delta \mathrm{Y}_{2} \quad\left(\text { as } \Delta \mathrm{Y}_{2}=-\Delta \mathrm{Y}_{1}\right) .
$$

This leads to a higher tax share $\mathrm{T} / \mathrm{Y}$ - though rates of taxation are not increased.

- Transfer payments rise by

$$
\Delta \mathrm{Tr}=\operatorname{tr} \cdot \Delta \mathrm{Y}_{\operatorname{Tr}}
$$

(The assessment basis for transfer payments increases if the concentration of the income distribution rises. One reason is that more income earners get transfer payments, the other reason is that previous transfer recipients get higher payments.)

The result is a higher share of transfer payments $\mathrm{Tr} / \mathrm{Y}$ - though the transfer rate and the income below which individuals qualify for transfers $Y_{\min }$ remain unchanged.

Note that it would be mere chance, if $\Delta \mathrm{T}$ would equal $\Delta \operatorname{Tr}$ as both values are influenced by different factors:

- The increase of the taxes $\Delta \mathrm{T}$ depends on the two tax rates $t_{1}$ and $t_{2}$ and on the degree of income redistribution $-\Delta \mathrm{Y}_{1}=\Delta \mathrm{Y}_{2}$.

- The growth of the transfer payments $\Delta \mathrm{Tr}$ is influenced by the transfer rate tr and the rise of the assessment basis for the transfer payment $\Delta \mathrm{Y}_{\operatorname{Tr}}$ which again, depends on the extent of redistribution between the two groups of income earners and on the (unchanged) income distribution within the lower half of earners.

Nevertheless, for the sake of transparency of our argument, we assume:

$$
\Delta \mathrm{T}=\Delta \mathrm{Tr}=\Delta \mathrm{G} \text { and } \Delta \mathrm{T} / \mathrm{Y}=\Delta \mathrm{Tr} / \mathrm{Y}=\Delta \mathrm{G} / \mathrm{Y} \text { respectively. }
$$

This simple model only serves the purpose of demonstrating the essential problem. It cannot be used to predict how taxes, transfer payments and government spending, as a 
share of GDP, will increase in a specific economy if the income inequality rises by a definite extent.

This will be the result of a multitude of country-specific institutional rules. The system of taxation, for example, is of particular importance, especially the share of indirect taxes of tax revenue, the form of progressive taxation and tax exemptions. Furthermore, the form and amounts of social welfare and the preconditions for drawing benefits are relevant. Accordingly different macroeconomic models are required for the simulation of the effects of a rising income inequality on the shares of taxes, transfer payments and government expenditures in different economies.

\section{2. "Strategical Options" of Economic Policy}

Which options do politicians have to respond to an increase of the tax burden and higher public spending, as a share of economic output? Which "scenarios" are possible and in which way do they "force" politicians to move away from previous value judgements concerning redistribution, duties and responsibilities of the government and "social standards"?

One can imagine four "scenarios":

(1) Politicians hold fast to previous value judgements. Accordingly, they do not change tax rates, quantity and quality of public goods and the system of transfer payments. In that case they have to accept that the tax share and the share of transfer payments in GDP increase and hence the share of government spending goes up.

(2) Fearing that the international competitiveness of the economy could deteriorate, economic politicians decrease tax rates (or broaden tax exemptions) until the tax share of the economy reaches its old level. (The background is that macroeconomic key figures, like tax shares in GDP, are often used for international comparisons and for measuring competitiveness.) These tax cuts lead to less redistribution though the concentration of market incomes has increased. Furthermore, they cause a budget deficit and hence a rising public debt (as transfer payments remain on their higher level).

The increasing public debt puts politicians under the obligation to act because rising government spending is often interpreted as a sign of the increasingly "exorbitant" demands of the state (Plickert, 2007). Moreover, the increase of the tax ratio is often equated with a loss of international competitiveness. Therefore politicians do not only aim at the old tax share but also at the old share of government spending in GDP, which leads to the third and forth scenario:

(3) If politicians do not lower "social standards", the increased share of transfer payments in GDP implies a reduction of government expenditures for consumption and investment. This deteriorates the supply with public goods, i.e. it interferes with the needs of a modern educational system, a well functioning infrastructure and an efficient public administration including high public safety. 
(4) The alternative way for economic politicians is to "downsize" social benefits, especially to pay less social welfare and to reduce contributions to (public) health care and pension schemes.

(Another possibility is combining a reduction of public spending for consumption and investment and a decrease of "social standards".)

\section{Table 1: "Scenarios" for Economic Policy in Case of Rising Income Inequality}

Table 1 gives an overview of politicians' options in handling the implications of a rising income concentration. They either have to ignore the criticism that a higher tax share in GDP and higher government expenditures indicate a lower international competitiveness and "exorbitant" demands of the state, or they have to diverge from established value judgements in the society.

In most countries a rising concentration of market incomes will induce economic politicians to say good-bye to existing and accepted value judgements about an "adequate" supply with public goods, redistribution and "social standards". However, if the citizens (and voters) hold on to their value judgements and politicians refuse to follow these, this might result in disenchantment with politics.

\section{Research outlook}

The aim of our short discussion paper is to initiate comparative research in several European countries and North America about the development of the income distribution and its implications for state activities.

- The starting point is the question if and how much the income distribution in the investigated countries changed. This requires an agreement on how to measure income inequality and its change, i.e. similar statistical metrics have to be used.

- In order to investigate how much the observed rise of the income concentration would have increased the share of transfer payments and the share of taxes in GDP ceteris paribus (i.e. without any change of tax system; system of transfer payments and supply of public goods) macroeconometric models are necessary. These countryspecific models "mirror" different institutions and institutional rules. On this basis the differing effects of a rising income concentration can be simulated.

- Against this background researchers should focus on the question, which options the different politicians chose if the income inequality in their country increased. Did they accept an increase of the tax share, the share of transfer payments and the share of government spending in GDP or did they diverge from value judgements concerning redistribution, "social standards" and/or an "adequate" supply with public goods?

- Especially from a political point of view, it is interesting to investigate whether the citizens and voters of the different countries have accepted these changes of value judgements or have instead reacted with "disenchantment with politics". 


\section{References}

Alderson, A.S. and Nelsen, F., 2002. Globalization and the Great U-Turn: Income Inequality Trends in 16 OECD Countries. American Journal of Sociology, 107 (5), pp. $1244-1299$.

Atkinson, A.B., 2003. Income Inequality in OECD Countries: Data and Explanations, CESinfo Economic Studies 49 (4), pp. 479 - 513.

Berthold, N., 2007. Die neue Ungleichheit, Frankfurter Allgemeine Zeitung, 09/01/2007.

Gottschalk, P. and Smeeding, T.M., 1997. Cross-National Comparisons of Earnings and Income Inequality. Journal of Economic Literature, 35 (2), pp. 633 - 687.

Gustafsson, B. and Johansson, M., 1999. In Search of Smoking Guns: What Makes Income Inequality Vary in Different Countries? American Sociological Review, 64 (44), pp. $585-605$.

Harrison, B. and Bluestone, B., 1988. The Great U-Turn: Corporate restructuring and the polarization of America, New York.

Institut der deutschen Wirtschaft, ed., 2007. Staatsverschuldung - Wege aus der Schuldenfalle, Köln.

International Monetary Fund, 2007. World Economic Outlook, Paris.

Krämer, H.D., 2005. Die funktionale Einkommensverteilung seit Beginn der 1999er Jahre. Einige Bemerkungen zu aktuellen Veränderungen der Arbeitseinkommensquote. In: G. Huber and H.D. Krämer, eds. Einkommensverteilung, technischer Fortschritt und struktureller Wandel, Festschrift für Peter Kalmbach, Marburg, pp. $53-84$.

OECD, 2008. Growing unequal? Income distribution and poverty in OECD countries, OECD, Paris.

Plickert, P., 2007. Die Ansprüche des Staates stoßen an Grenzen, Frankfurter Allgemeine Zeitung 07/13/2007.

Smeeding T. M., 2004. Twenty Years of Research on Income Inequality, Poverty, and Redistribution in the Developed World: Introduction and Overview. SocioEconomic Review 2 (2), pp. 149-163. 
Table 1: "Scenarios" for Economic Policy in Case of a Rising Income Inequality

\begin{tabular}{|c|c|c|c|c|c|}
\hline & $\mathrm{T}$ & G & $\operatorname{Tr}$ & $\mathrm{C}_{\mathrm{G}}+\mathrm{I}_{\mathrm{G}}$ & \\
\hline - Initial situation & & & & & $\mathbf{T}=\mathbf{G}$ Balanced budget (assumption) \\
\hline - Consequences of a rising income inequality & \multicolumn{4}{|c|}{$\begin{array}{l}\text { Changes compared to } \\
\text { the initial situation }\end{array}$} & \\
\hline $\begin{array}{l}\text { 1. Adhering to previous (socially accepted) value judgements } \\
\text { about "social standards", the degree of redistribution by taxes } \\
\text { and an "adequate" supply with public goods. }\end{array}$ & $\uparrow$ & $\uparrow$ & $\uparrow$ & 0 & $\begin{array}{l}\mathbf{T}=\mathbf{G} \text { (simplifying assumption) } \\
\text { Taxes, transfer payments and government expenditure, } \\
\text { as well as share of GDP, increase, whereas government ex- } \\
\text { penditures for consumption and investment remain un- } \\
\text { changed. }\end{array}$ \\
\hline $\begin{array}{l}\text { 2. Decreasing tax rates (and redistribution) to return to the pre- } \\
\text { vious tax share in GDP for "regaining" international competi- } \\
\text { tiveness (otherwise value judgements are maintained). }\end{array}$ & 0 & $\uparrow$ & $\uparrow$ & 0 & $\begin{array}{l}\mathbf{T}<\mathbf{G} \text {, i.e. a budget deficit leads to a higher public debt. } \\
\text { The tax share remains unchanged, whereas transfer payments } \\
\text { and government spending, as share of GDP, increase. }\end{array}$ \\
\hline $\begin{array}{l}\text { Returning to previous tax share and government spending share } \\
\text { in GDP keeping international competitiveness and balanced } \\
\text { budget in view. }\end{array}$ & 0 & 0 & & & $\begin{array}{l}\mathbf{T}=\mathbf{G} \text {, i.e. balanced budget, by reverting to the tax share } \\
\text { and government spending share in GDP in the initial situation. }\end{array}$ \\
\hline $\begin{array}{l}\text { 3. Adhering to value judgements concerning "social standards" } \\
\text { implies a reduction of government expenditures for consump- } \\
\text { tion and investment. }\end{array}$ & 0 & 0 & $\uparrow$ & $\downarrow$ & $\begin{array}{l}\text { - The increased share of transfer payments "forces" the } \\
\text { government to spend less for consumption and investment. }\end{array}$ \\
\hline or & & & & & or \\
\hline $\begin{array}{l}4 \text { Adhering to value judgements concerning an "adequate" } \\
\text { supply with public goods implies a decrease of "social stan- } \\
\text { dards" (so that transfer payments do not increase, except } \\
\text { for the fact that income inequality has risen). }\end{array}$ & 0 & 0 & 0 & 0 & $\begin{array}{l}\text { - If the government wants to return to the share of transfer } \\
\text { payments in GDP in the initial situation it "is forced" to } \\
\text { decrease the "social standards". }\end{array}$ \\
\hline or & & & & & or \\
\hline $\begin{array}{l}\text { A combination of a reduction of public expenditures for con- } \\
\text { sumption and investment and a decrease of "social stan- } \\
\text { dards". }\end{array}$ & 0 & 0 & $\begin{array}{l}\uparrow \\
\mathrm{I}\end{array}$ & $\begin{array}{l}\mathrm{I} \\
\downarrow\end{array}$ & $\begin{array}{l}\text { - To reach a moderately increased share of transfer pay- } \\
\text { ments the government "is forced" to decrease "social stan- } \\
\text { dards"and to spend less for consumption and investment. }\end{array}$ \\
\hline
\end{tabular}

